\title{
Temporal and spatial history of Rift Valley fever in South Africa: 1950 to 2011
}

\author{
Authors: \\ Nicolaas J. Pienaar ${ }^{1,2}$ \\ Peter N. Thompson ${ }^{1}$ \\ Affiliations: \\ ${ }^{1}$ Department of Production \\ Animal Studies, University of \\ Pretoria, South Africa \\ ${ }^{2}$ Directorate Animal Health, \\ Department of Agriculture, \\ Forestry and Fisheries, \\ South Africa \\ Correspondence to: \\ Nicolaas Pienaar \\ Email: \\ HannesP@daff.gov.za \\ Postal address: \\ Private Bag X04, \\ Onderstepoort 0110, \\ South Africa \\ Dates: \\ Received: 07 Oct. 2011 \\ Accepted: 24 Nov. 2012 \\ Published: 05 Mar. 2013 \\ How to cite this article: \\ Pienaar, N.J. \& Thompson, \\ P.N., 2013, 'Temporal and \\ spatial history of Rift Valley \\ fever in South Africa: 1950 to \\ 2011', Onderstepoort Journal \\ of Veterinary Research 80(1), \\ Art. \#384, 13 pages. http:// \\ dx.doi.org/10.4102/ojvr. \\ v80i1.384

\section{Copyright:} \\ (C) 2013. The Authors. \\ Licensee: AOSIS \\ OpenJournals. This work \\ is licensed under the \\ Creative Commons \\ Attribution License. \\ Read online:

Several outbreaks of Rift Valley fever (RVF) have been documented in South Africa since it first occurred in the country in 1950. However, there is no comprehensive account of the timing, location and extent of all known outbreaks. As part of a study investigating the epidemiology of RVF in South Africa, a full history of outbreaks was compiled using references to the disease in South Africa from scientific literature, annual reports, disease reports and animal disease databases. The geographic location and temporal occurrence of each outbreak were recorded as accurately as allowed by the available records. The result was a better and more complete picture than has hitherto been available of the spatial and temporal distribution of RVF in South Africa for the period between 1950 and 2011. Several smaller outbreaks which had not been described previously in literature were documented. Extensive outbreaks occurred in the central interior of the country (Free State, Eastern Cape and Northern Cape provinces), interspersed with smaller outbreaks or long intervening periods of absence, whilst smaller outbreaks occurred in the eastern part of the country (KwaZulu-Natal, Mpumalanga and Gauteng).

\section{Introduction}

Rift Valley fever (RVF) is a zoonotic viral disease of ruminants that is transmitted by mosquitoes of various genera. In animals RVF can be inapparent, or cause peracute or acute disease. The most noted effect is abortions, but it can also cause fever leading to mortalities in young animals, especially lambs. Humans can contract RVF following contact with tissues of infected animals. The symptoms in humans are mostly those of a febrile, influenza-like illness, but in severe cases it can lead to haemorrhagic fever, encephalitis, retinal haemorrhage and even death (Swanepoel \& Coetzer 2004).

RVF typically occurs in South Africa as outbreaks interspersed with long periods of absence. The mechanisms of virus survival during the interepidemic periods are unknown, but may include transovarial transmission in the vectors or low-level transmission between vectors and hosts (Swanepoel \& Coetzer 2004). New outbreaks are triggered by an explosion in vector numbers as a result of the abundance of water due to increased rainfall, flooding or even human activity such as dam building. Areas where RVF has occurred in the past are likely to experience re-occurrences (Gerdes 2004).

RVF was first diagnosed in the Kenyan Rift Valley in 1931 (Daubney, Hudson \& Garnham 1931) and has since also been diagnosed in Zimbabwe, Zambia, Mozambique, Namibia, Madagascar, Tanzania, Somalia, Sudan, Egypt, Senegal, Mauritania and on the Arabian Peninsula, amongst others (Swanepoel \& Coetzer 2004). Occurrences of RVF outbreaks in Kenya have been detailed by Linthicum et al. (1999) and by Murithi et al. (2010).

Since the first recorded occurrence in South Africa in 1950 (Alexander 1951), a large number of outbreaks have been listed by Swanepoel and Coetzer (2004), but several of the smaller outbreaks have never been recorded in the literature. Although information regarding these outbreaks is available in veterinary services disease reports and annual reports, no comprehensive record of RVF outbreaks in South Africa exists. This information is important not only for understanding the epidemiology of the disease but also in guiding management attempts. This paper documents the occurrence of RVF in South Africa on a temporal and spatial basis and attempts to document all the recorded instances of RVF outbreaks in South Africa.

\section{Materials and methods}

To fully document the occurrence of RVF in South Africa, a comprehensive search was conducted of both published and unpublished literature. Annual reports of the National Department of Agriculture and the Directorate of Veterinary Services/Animal Health from 1950 to 2000 were 
searched. Since its first occurrence in South Africa in 1950, RVF has been a notifiable or reportable disease and therefore the disease reports of the veterinary services were considered to be a good source of information on occurrence of the disease. Annual reports of individual veterinary laboratories were not available. However, facilities for laboratory confirmation of RVF were already in place in 1950 and as the laboratory services were part of the veterinary services all occurrences of RVF mentioned in these reports were considered to have been laboratory confirmed, unless otherwise mentioned. If the disease had not been confirmed in a laboratory but was documented in a report, we mentioned it in our results but did not include it in our statistics. Disease reports to the World Organisation for Animal Health (OIE) and the Southern African Regional Commission for the Conservation and Utilisation of the Soil (SARCCUS) were also included in the search. A literature search combining the keywords 'Rift Valley fever' and 'South Africa' was performed on the electronic databases Pubmed (U.S. National Library of Medicine, Bethesda), ScienceDirect (Elsevier, Amsterdam) and $\mathrm{CABdirect}$ (CAB International, Wallingford). All articles that indicated a year and location of an outbreak, including reports of RVF in humans, were used.

Disease reports from South African veterinary regions and provincial veterinary services between 1950 and 2011, stored in the archives of the Directorate Animal Health, and the animal disease database of the Directorate Animal Health (1992-2011) were major sources of reports on RVF in South Africa. Disease reports prior to 1994 referred to veterinary regions, which were demarcated according to the main animal production activities in each region. The Veterinary Services of South Africa were also divided into these regions. Figure 1 shows a map and a list of these regions, as well as the pre-1994 provincial boundaries of South Africa. After 1994, veterinary services were provincialised according to the new provincial boundaries (Figure 2).

All available information on RVF outbreaks was collated by season (July-June), covering a total of 61 seasons between 1950/1951 and 2010/2011. An outbreak was defined as the occurrence of laboratory-confirmed RVF in a specified location during a season. In this study, 'epidemic' is used to refer to an occurrence of multiple related outbreaks in the same season. For each outbreak, as much detail as possible was obtained with respect to the location (region, district or, if possible, exact location) and time (season or, if possible, month) of the event. South Africa was divided into 462 blocks spanning a half degree latitude by a half degree longitude and each outbreak was assigned to one or more of these blocks. This was necessary to account for the temporal variation in the spatial resolution of the outbreak reports. However, in some cases the spatial resolution of the veterinary services disease reports was very low and only the veterinary region or district was mentioned. In such cases, all the blocks within that area were recorded as having experienced an outbreak, except where it was known or was concluded following further investigation that an outbreak had never occurred or was extremely unlikely to have occurred in a certain area.
The cumulative number of seasons during which each block had experienced an outbreak was then calculated and plotted on a map of the country. Where the month of occurrence was mentioned, outbreaks were also tabulated by season to show the temporal distribution of outbreaks within each season. A detailed analysis of the association between potential climatic and other risk factors and the occurrence of RVF in South Africa will be reported on separately.

\section{Results}

During the 61-year study period (1950-2011) one or more RVF outbreaks were reported in 27 seasons. South Africa experienced three major epidemics that affected an extensive area of the country (1950-1951, 1974-1976 and 2010-2011). The rest of the reports concerned smaller epidemics, individual outbreaks or isolated cases, some of which were not laboratory confirmed. All reported outbreaks are detailed by season and a summary of all the laboratoryconfirmed outbreaks is given in Table 1. Maps show post-

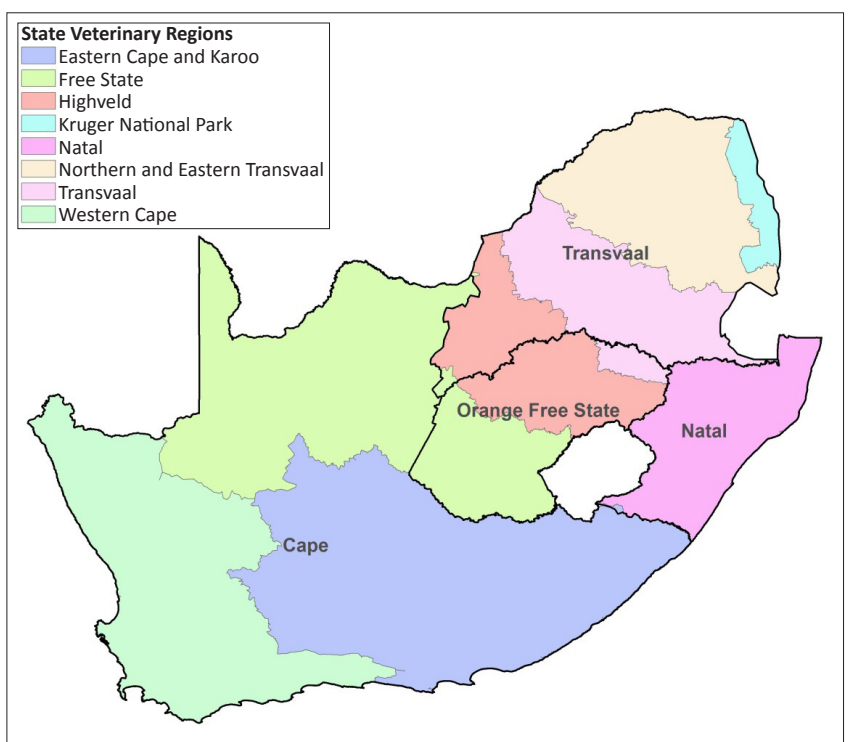

FIGURE 1: Veterinary regions and provinces of South Africa before 1994.

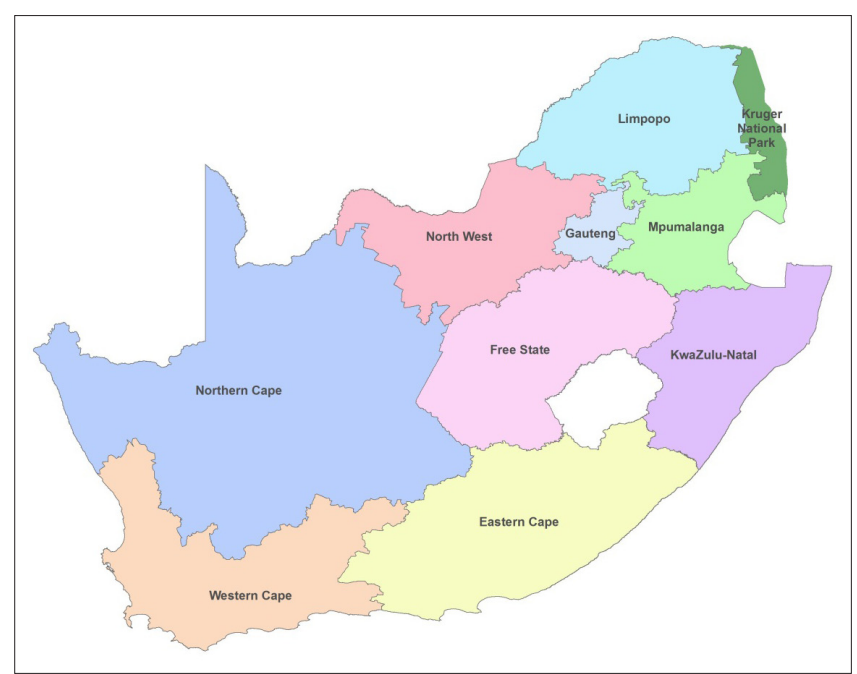

FIGURE 2: South African provincial boundaries after 1994 and the Kruger National Park. 
1994 provincial boundaries. However, some references are made to veterinary regions, the names and boundaries of which differ in many cases from those of both previous and present provinces of South Africa (refer to Figures 1 and 2).

Since separate laboratory reports could not be found, it was assumed that, unless otherwise stated, all RVF outbreaks reported in the annual reports of the Veterinary Services were laboratory confirmed. Several reports stated that outbreaks were reported but could not be confirmed by the laboratory; very little information was given and these reports are mentioned in the following sections but not included in our statistics.

\section{0-1951}

RVF was recorded in South Africa in this period in the northern Cape Province, western Orange Free State and the southern Transvaal (Figure 3). This was the first time RVF had been diagnosed in South Africa and no reports of any similar disease prior to this epidemic could be found. It started in the western Free State in December 1950 and continued until April 1951. Specific areas mentioned are the Wolwespruit and Dealesville areas of the Boshof district, Vaalhartz, the Vaal River Barrage, Loskop Dam, Koffiefontein and Standerton (Alexander 1951). At first the disease was not recognised, but after a veterinarian performing a post-mortem inspection on a farm south of Johannesburg fell ill, it was recognised as RVF (Mundel \& Gear 1951) and the virus (lineage O) was isolated (Grobbelaar et al. 2011). During this epidemic sheep mortalities were estimated at 100000 , together with an estimated 500000 abortions (Gerdes 2004). It was recognised that the epidemic was associated with the 'panveld' area of the Orange Free State, characterised by shallow grassland depressions that fill with water seasonally (Alexander 1951).

\section{1-1952}

A single laboratory-confirmed diagnosis of RVF on 30 January 1952 was reported from the farm Weltevreden in the Wolvenspruit area of the Boshof district (Figure 4) (Van der Linde 1953).

\section{2-1953}

During April 1953 outbreaks were confirmed (positive mouse protection test) in the Gannapan and Legpan areas of the Fauresmith (Luckhoff) district, northwest of Luckhoff in the Orange Free State (Figure 4). These pans have a geographical reference of $29^{\circ} 40^{\prime} \mathrm{S}, 24^{\circ} 40^{\prime} \mathrm{E}$. Farms affected were Eldorado, Legpan, Bossiespan A \& B, Wolvenkraal, Nelsdam, Overskot, Koppiesdam, De Rif, Alpha and Wolvenplaat. It was also noted that the outbreaks were associated with the flooding of the nearby pans (Van der Linde 1953). A team from the South African Institute for Medical Research was sent to investigate. Their report mentioned that several people contracted the disease after handling meat and also suggested that standing water in pans could have contributed to the outbreak (Gear et al. 1955).

\section{3-1954}

No outbreaks of RVF were found although several suspected outbreaks were investigated (Alexander 1955a). No further details on the suspected outbreaks could be found.

\section{4-1955}

A large number of samples from suspected RVF outbreaks were tested, but no outbreaks were confirmed (Alexander 1955b). No further details were given on the suspected outbreaks.

\section{5-1956}

A total of 28 outbreaks were reported from the Orange Free State (Wesselsbron, Odendaalsrus, Soutpan, Dealesville, Boshof, Hoopstad, Ventersburg and Bothaville districts), as shown in Figure 5 (Alexander 1956). Virus isolation confirmed that the outbreak was caused by a lineage I RVF virus (Grobbelaar et al. 2011).

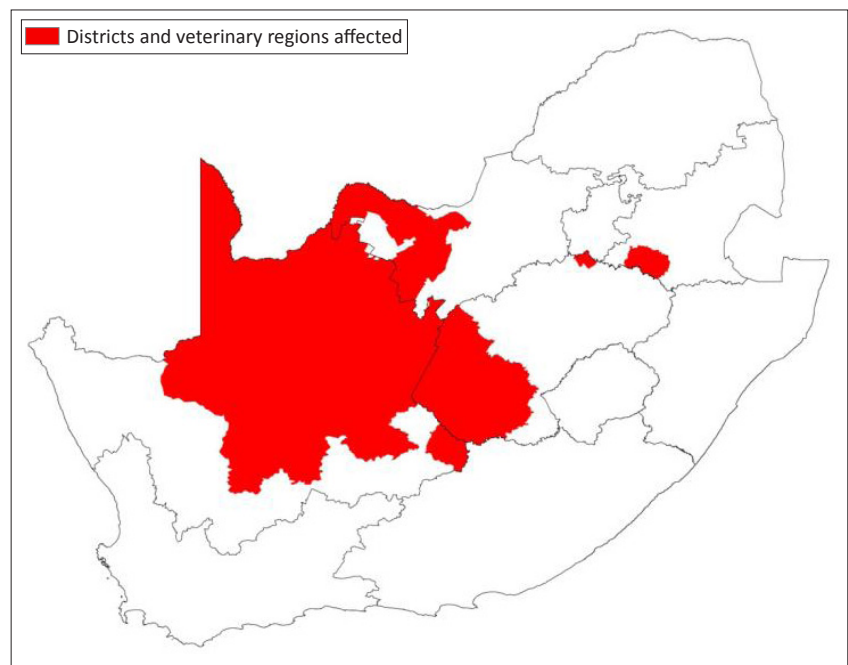

Post-1994 provincial boundaries shown

FIGURE 3: Districts and veterinary regions affected by Rift Valley fever in South Africa, 1950-1951.

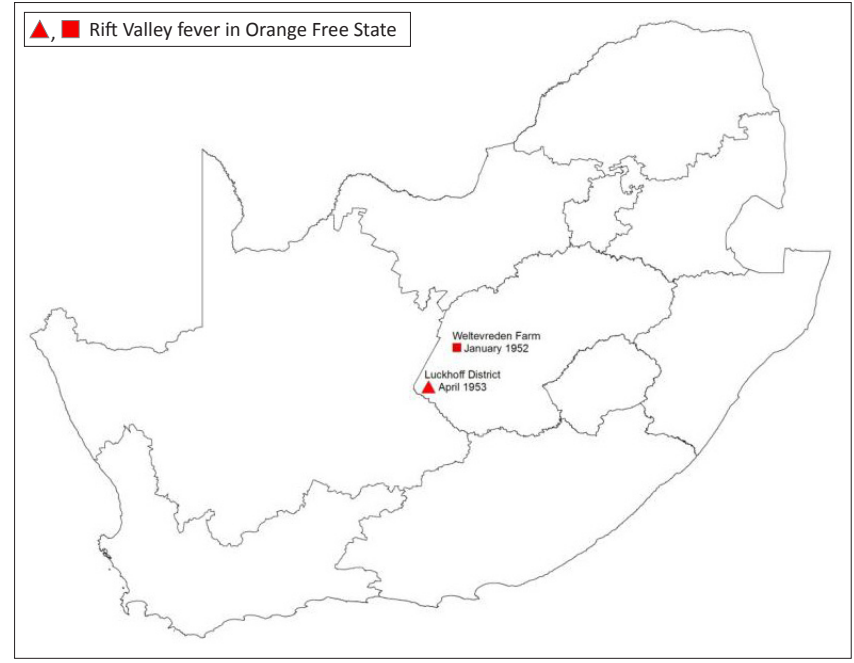

Post-1994 provincial boundaries are shown.

FIGURE 4: Rift Valley fever in the Orange Free State in South Africa between 1951 and 1953. 


\section{6-1957}

The annual report for the period 1956-1957 mentions two outbreaks in the western Orange Free State, but does not provide further detail regarding the exact place and time (Division of Veterinary Services 1957).

\section{7-1969}

No outbreaks of RVF were reported (Division of Veterinary Services 1958, 1959, 1960, 1961, 1962, 1963, 1964, 1965, 1966, $1967,1968,1969)$. Neither two suspected outbreaks in the Orange Free State in the period 1965-1966 nor several suspected outbreaks in the period 1966-1967 could be confirmed by the laboratory (Division of Veterinary Services 1966, 1967).

\section{9-1970}

Severe livestock losses occurred owing to outbreaks reported from the Standerton, Frankfort, Kroonstad, Koppies, Odendaalsrus, Vryburg and the Lower Umfolozi districts (Figure 6) (Division of Veterinary Services 1970).

\section{0-1973}

No outbreaks were reported for this period (Division of Veterinary Services 1971, 1972, 1973).

\section{3-1974}

During this period South Africa's largest RVF epidemic began. It had the largest extent, lasted three years and likely affected more animals than any other epidemic, although no reliable estimates are available. A mortality rate of up to 95\% was reported amongst young lambs, with widespread abortions and deaths in adult animals (Division of Veterinary Services 1974). The outbreak was caused by a lineage L RVF virus (Grobbelaar et al. 2011). All areas except the winter rainfall area, the Eastern Transvaal and Transvaal reported widespread occurrence of the disease (Figure 7). In Natal the disease occurred only in the Eshowe State Veterinary Area. The Kimberley, Bloemfontein and Fauresmith areas and the Eastern Cape and Karoo veterinary region suffered severe losses owing to the disease. Heavy rains and large tracts of standing water created ideal conditions for the RVF virus vectors. The epidemic continued through the winter (which was warmer than average), spilling over into the next season (Division of Veterinary Services 1974).

\section{4-1975}

The major epidemic of 1973-1974 continued during this season, being most severe in the north-western Cape Province, southern Orange Free State and the western parts of Transvaal (Figure 8). Other areas specifically mentioned were the Calvinia area in September 1974, areas along the Orange River, the Nyl River valley near Potgietersrus, and East Griqualand. A few cases were reported from Natal (Division of Veterinary Services 1975). Areas specifically mentioned

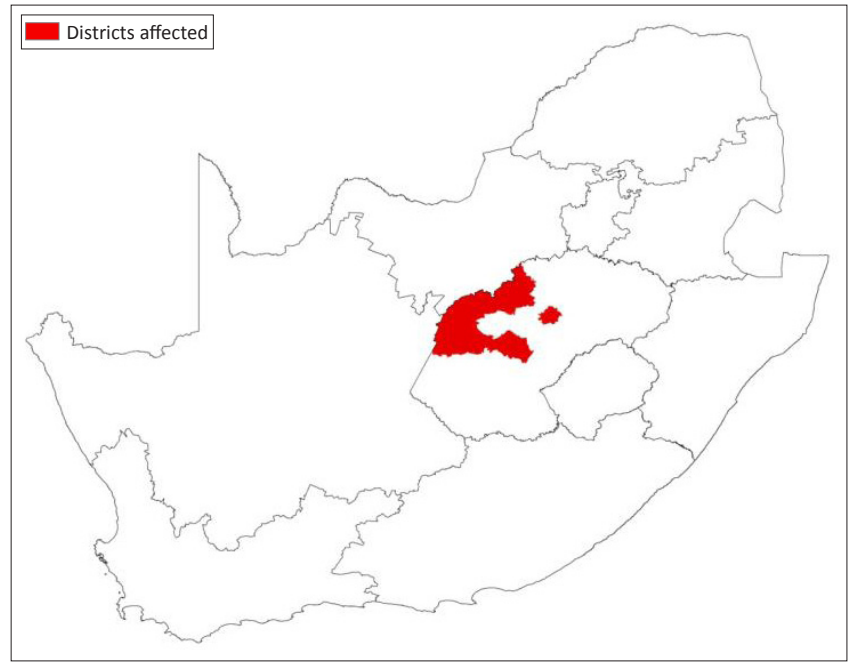

Post-1994 provincial boundaries shown.

FIGURE 5: Districts affected by Rift Valley fever in South Africa during the period 1955-1956.

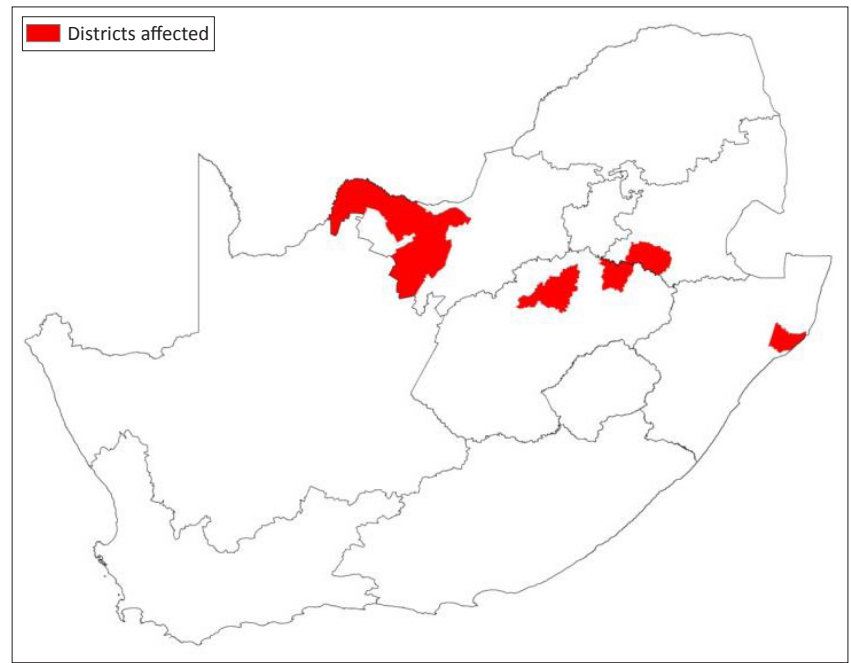

Post-1994 provincial boundaries are shown.

FIGURE 6: Districts affected by Rift Valley fever in South Africa during 1969-1970.

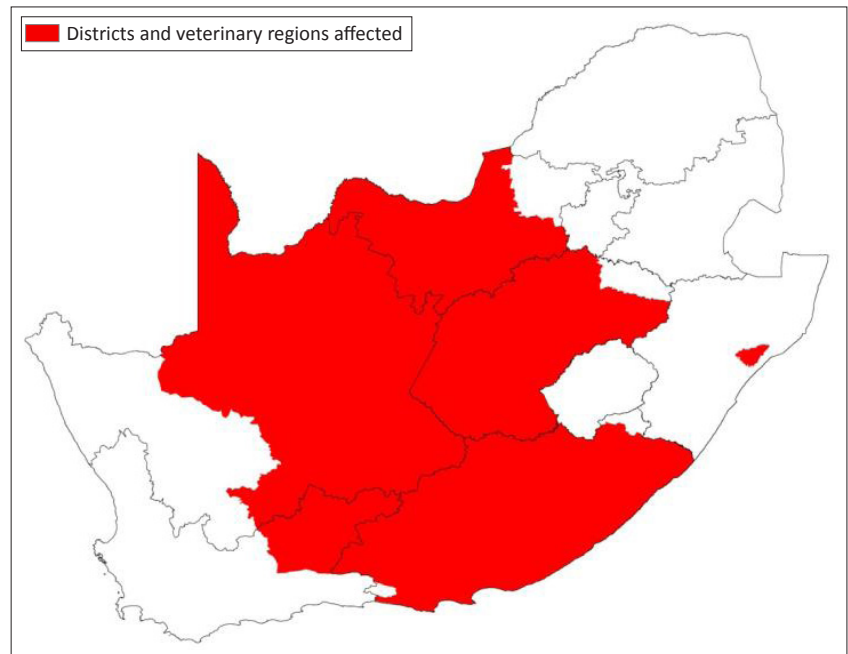

Post-1994 provincial boundaries are shown.

FIGURE 7: Veterinary regions and one district in Natal affected by the 19731974 Rift Valley fever epidemic in South Africa. 
as being affected by this epidemic in an unpublished report of the Western Cape Veterinary region (Anonymous 1976) were Steinkopf, Springbok, Brandvlei, Sutherland, Williston, Nieuwoudtville, Vredendal, Lutzville, Calvinia (February 1975), Clanwilliam, Vanrhynsdorp (October 1974), Kenhardt (September 1974), Pella (August 1974), Graafwater (May 1975), Lamberts Bay and Boesmanland (May 1975). During this epidemic human cases appeared to be more severe, with more complications and deaths than had previously been noted (McIntosh et al. 1980a). Lineage L RVF virus was isolated from several human cases (Grobbelaar et al. 2011). Barnard and Botha (1977) published a map indicating reported RVF outbreaks, which is included in Figure 8.

\section{5-1976}

The epidemic that had begun in 1973 continued, but with fewer losses than during the previous seasons. The Kenhardt district reported a severe outbreak towards the end of the season and a few cases were reported from the Pietermaritzburg district. No cases were reported from the Northern and Eastern Transvaal regions (Division of Veterinary Services 1976a). An unpublished report of the Western Cape Veterinary region (Anonymous 1976) mentions outbreaks in the Brandvlei area.

\section{6-1977}

A few outbreaks were reported from the Mtunzini and Lower Umfolozi districts of Natal and the Queenstown and Middelburg areas of the eastern Cape Province (Figure 9) (Division of Veterinary Services 1977a). The monthly disease reports (Division of Veterinary Services 1976b, 1977b) from the regional veterinary services reported outbreaks in Gordonia in the Free State region (August 1976), the Vryburg district of the Free State region (September 1976), the Middelburg and Welkom districts of the Free State region (October 1976), the Viljoenskroon district of the Highveld region and Vryburg district of the Free State region (November 1976), the Queenstown district of the Eastern Cape and Karoo region (January 1977), the Queenstown and Middelburg districts of the Eastern Cape and Karoo region (February 1977), a few cases from the Eastern Cape and Karoo region and a few suspected cases from the Free State region (March 1977).

\section{7-1978}

A few cases were reported from the Free State and the Eastern Cape and Karoo regions (Figure 10) (Division of Veterinary Services 1978a). The monthly disease reports from the various veterinary regions (Division of Veterinary Services 1977b, 1978b) reported outbreaks in the Koppies district of the Free State region, where an animal owner also contracted RVF (November 1977). The Middelburg Veterinary Laboratory confirmed one case in the Eastern Cape and Karoo region (January 1978) and reported a suspected case from Upington (May 1978). A private veterinarian reported a case from the Welkom district of the Free State region (February 1978).

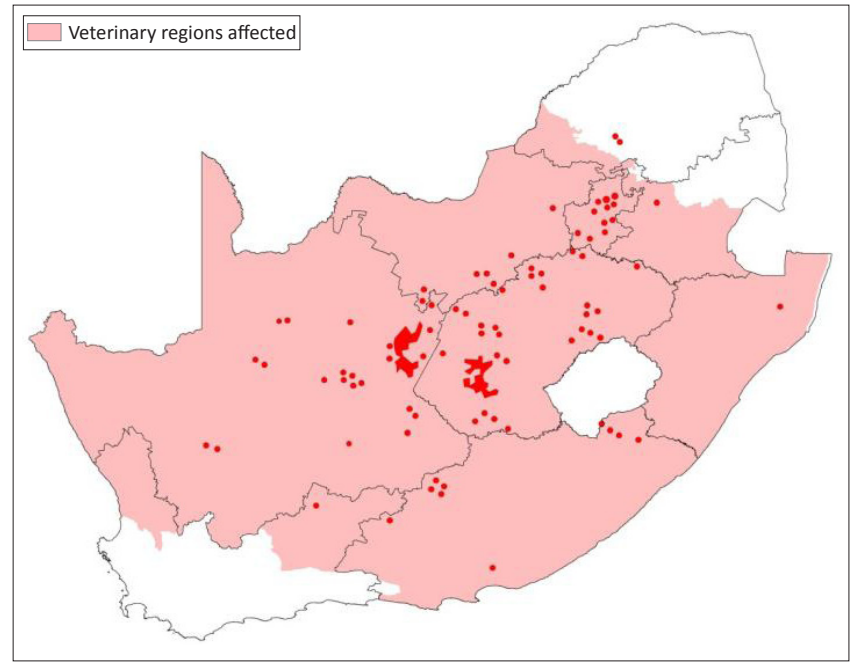

Source: Red dots are adapted from a map published by Barnard, B. \& Botha, M., 1977, 'An inactivated Rift Valley vaccine', Journal of the South African Veterinary Association 48, 45-48 Post-1994 provincial boundaries shown.

FIGURE 8: Veterinary regions affected by the Rift Valley fever epidemic during 1974 to 1975.

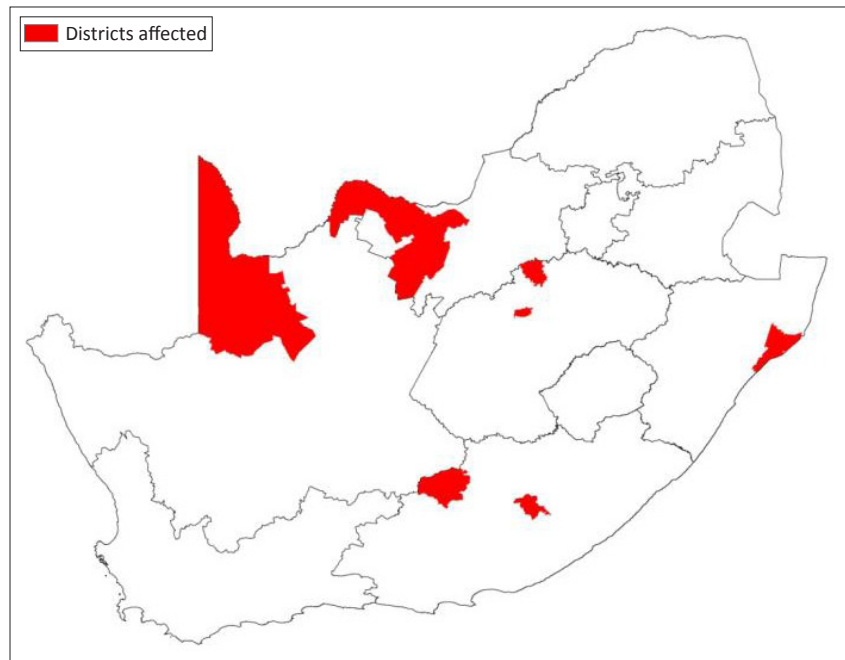

Post-1994 provincial boundaries shown

FIGURE 9: Districts affected by Rift Valley fever outbreaks in South Africa during 1976-1977.

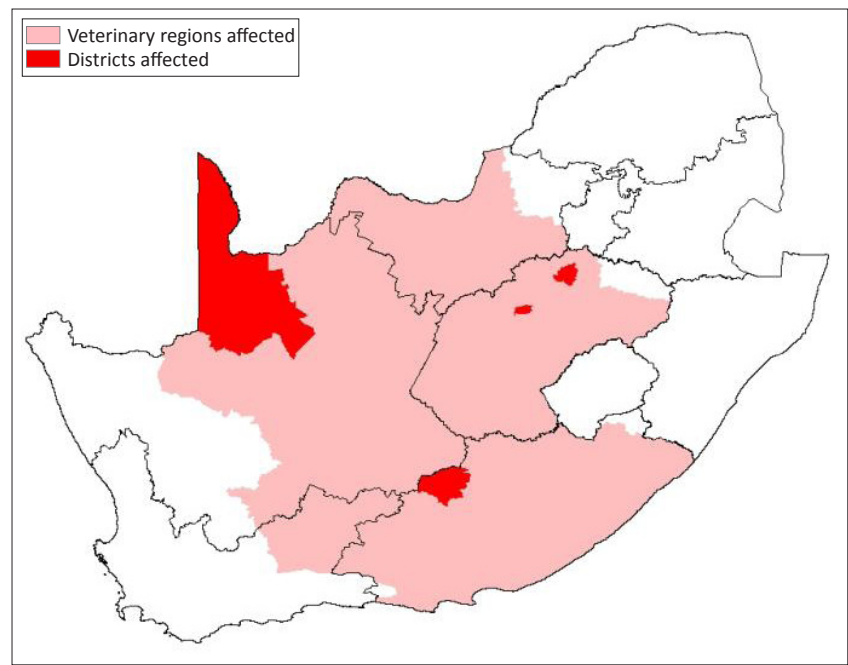

Post-1994 provincial boundaries shown.

FIGURE 10: Veterinary regions and districts affected by Rift Valley fever outbreaks in South Africa during 1977-1978. 


\section{8-1979}

The monthly disease reports of the veterinary regions (Division of Veterinary Services 1978b, 1979) reported outbreaks in the Middelburg and Prieska districts of the Eastern Cape and Karoo region (November 1978), the Pietermaritzburg and Mtonjaneni districts of the Natal region (December 1978), the Estcourt district of the Natal region (February 1979) and the Bethlehem district of the Free State region (April 1979) (see Figure 11).

\section{9-1980}

A single outbreak was reported in the Mtunzini district of the Natal region (Directorate of Animal Health 1980).

\section{0-1981}

Several outbreaks of RVF were reported by private veterinarians from the Highveld region, but none were laboratory confirmed (Directorate of Animal Health 1981).

\section{1-1982}

Three outbreaks were reported from the Hlabisa district in the Natal region, one outbreak was reported from the Eastern Cape and Karoo region, and another from the Bethlehem and Kroonstad areas (Figure 12) (Directorate of Animal Health 1982). A disease report for 1982 (Division of Veterinary Services 1983a) reported only one RVF outbreak, with no geographical reference, during April 1982, so it is likely that most of the mentioned outbreaks occurred between July and December 1981.

\section{2-1983}

Small outbreaks of RVF were reported from the Natal region and the Highveld region (Division of Veterinary Services 1983b). A disease report by the Division of Veterinary Services (1984a) reported RVF outbreaks during March, April and June 1983.

\section{3-1984}

Small outbreaks of RVF were reported from the Natal region and the Western Cape region (Figure 13) (Division of Veterinary Services 1984b). However, the outbreak in the Western Cape region was likely to have occurred in the northern part of the region (now the western part of the Northern Cape province), and therefore not within the winter rainfall region. A disease report by the Division of Veterinary Services (1984a) reported RVF outbreaks during October, November and December 1983, with 18 outbreaks in November 1983. The report by the Division of Veterinary Services for the following year (Directorate of Veterinary Services 1985c) reported one RVF outbreak in February and one in April 1984.

\section{4-1985}

Small outbreaks of RVF were reported from the Utrecht district of Natal and the Kroonstad and Henneman districts

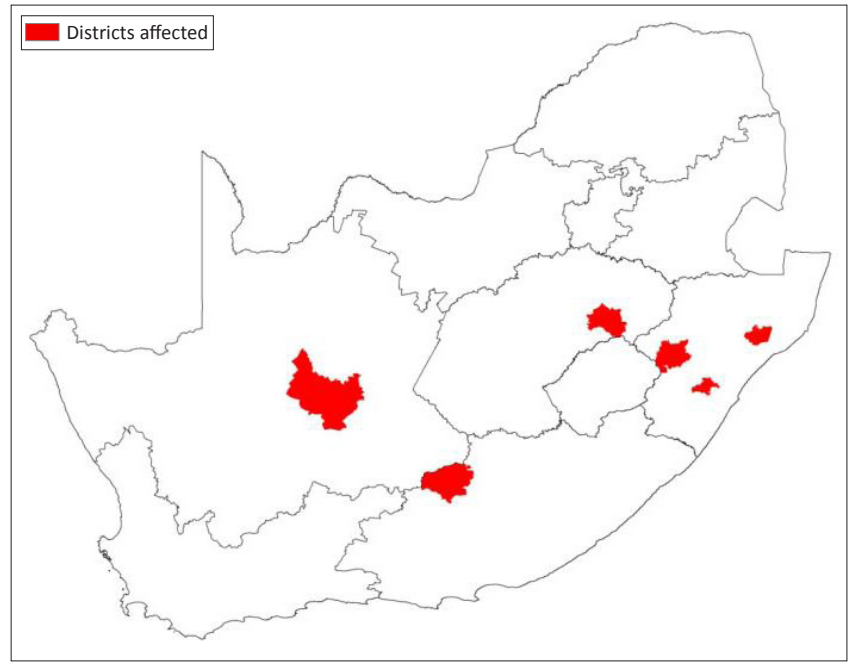

Post-1994 provincial boundaries shown.

FIGURE 11: Districts affected by Rift Valley fever outbreaks in South Africa during 1978-1979.

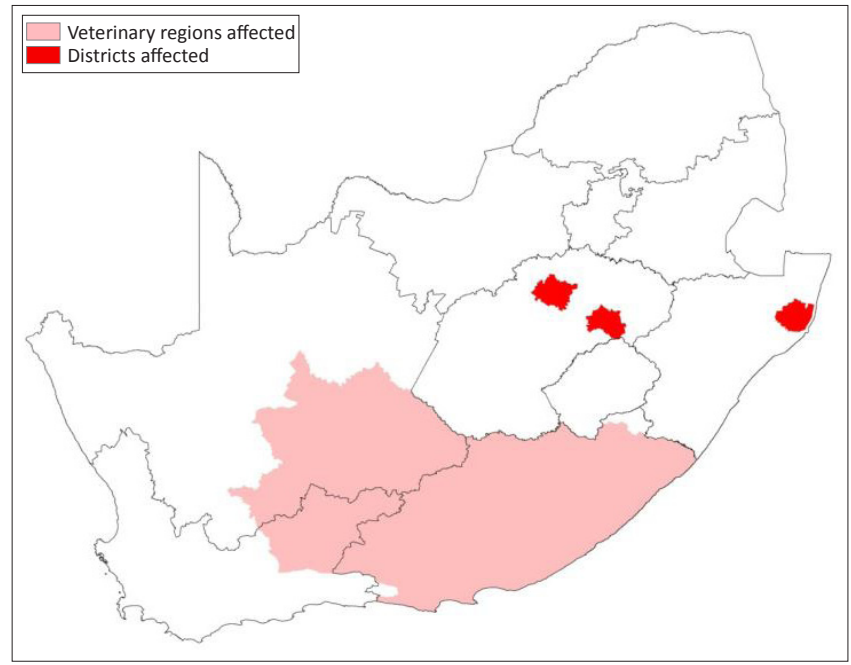

Post-1994 provincial boundaries shown.

FIGURE 12: Veterinary region and districts affected by Rift Valley fever outbreaks in South Africa during 1981-1982.

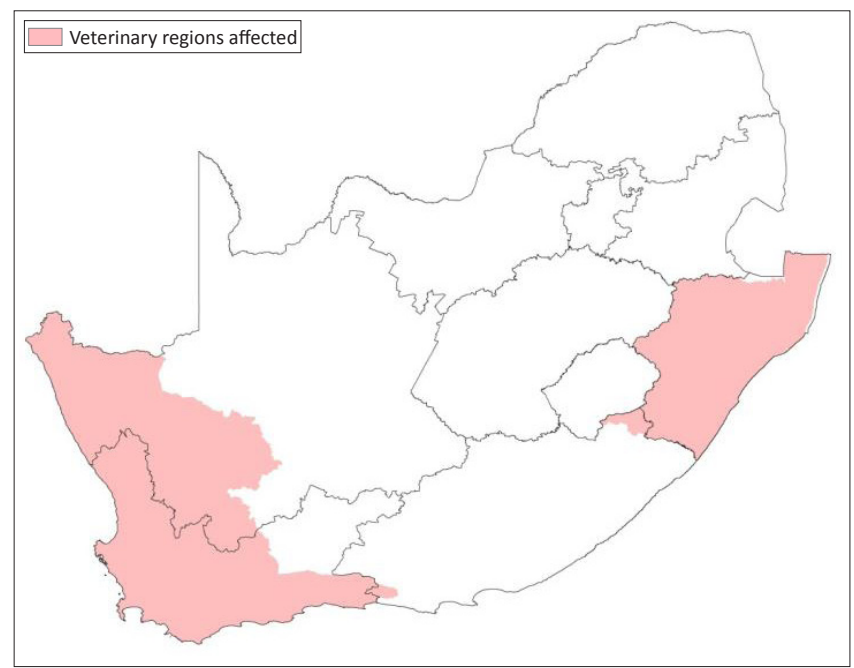

Post-1994 provincial boundaries shown.

FIGURE 13: Veterinary regions affected by Rift Valley fever outbreaks in South Africa during 1983-1984. 
in the Highveld region. A foetus from the Transvaal region tested positive for RVF (Figure 14) (Directorate of Veterinary Services 1985a). The report by the Division of Veterinary Services for 1984 (Directorate of Veterinary Services 1985c) reported no RVF outbreaks during the period July-December 1984.

\section{5-1986}

In this period, 13 outbreaks of RVF were reported from the Estcourt, Utrecht and Ubombo districts of the Natal region (Director of the Natal region of Veterinary Services 1986b) and seven outbreaks from the Port Elizabeth, Middelburg, Beaufort West, Hofmeyer and Graaff Reinett districts of the Eastern Cape and Karoo region (Figure 15) (Director of the Eastern Cape and Karoo region of Veterinary Services 1986; Directorate of Veterinary Services 1986b). The 1985 annual report to the OIE (Directorate of Veterinary Services 1985b) reports one outbreak during August 1985, without giving a geographic location. However, the monthly report from Natal for August 1985 indicated that an outbreak in the Estcourt district occurred during this month. The 1986 annual report to the OIE (Directorate of Veterinary Services 1986a) reported two outbreaks during February 1986. The monthly reports from Natal (Director of the Natal region of Veterinary Services 1986a) indicated outbreaks in Ubombo during February 1986 and in Hlabisa during March 1986.

\section{6-1987}

No cases of RVF were reported for this period (Directorate of Veterinary Services 1987). The annual disease report to the OIE for 1987 reported one case in March 1987, but did not give a geographic location (Directorate of Veterinary Services 1989a); the year of last occurrence was given as 1986

\section{7-1988}

The annual disease report to the OIE for 1987 mentioned one case in October 1987, but did not give a geographic location (Directorate of Veterinary Services 1989b).

\section{8-1989}

Although the climatic conditions were seemingly favourable for the disease and the Veterinary Services had predicted outbreaks, none were reported (Directorate of Animal Health 1989).

\section{9-1990}

The annual report to the OIE (Directorate of Veterinary Services 1989b) indicated one outbreak between January and March 1989, but without any indication of the geographic location of the outbreak.

\section{0-1991}

During February 1991 five outbreaks of RVF were reported from the Estcourt district and two from the Kliprivier district of Natal (Figure 16) (Director of the Natal region of Veterinary Services 1991).

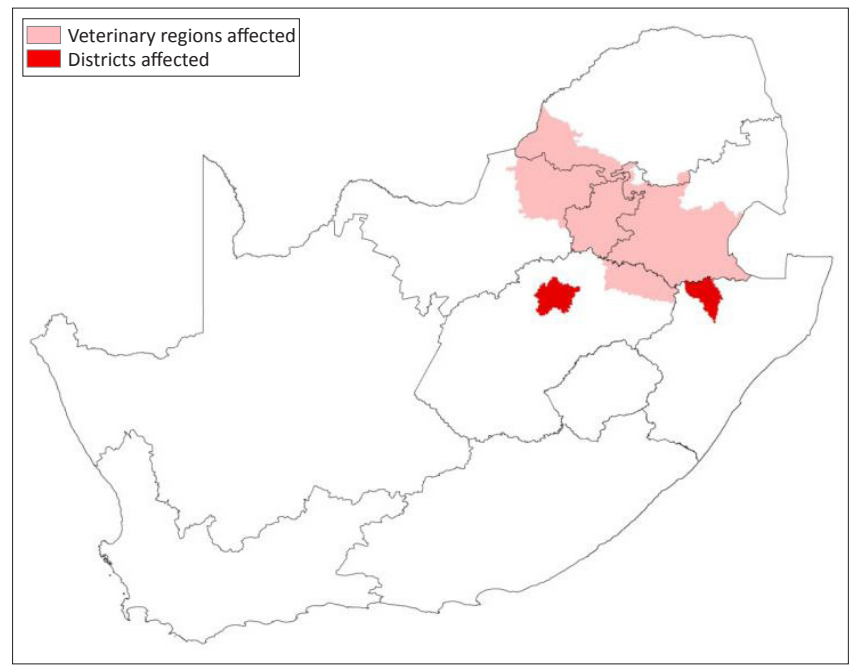

Post-1994 provincial boundaries are shown.

FIGURE 14: Veterinary regions and districts affected by Rift Valley fever outbreaks in South Africa during 1984-1985.

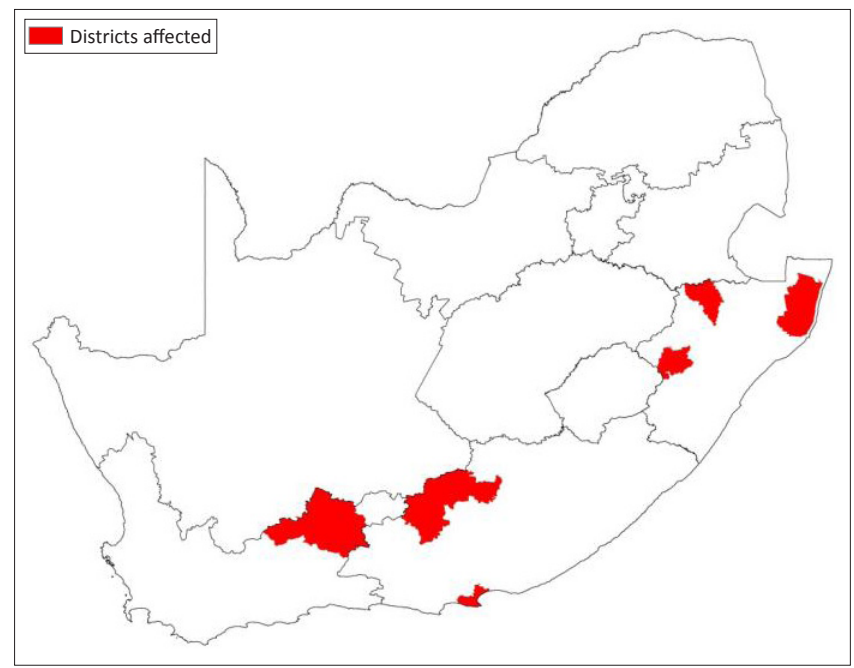

Post-1994 provincial boundaries are shown.

FIGURE 15: Districts affected by Rift Valley fever outbreaks in South Africa during 1985-1986.

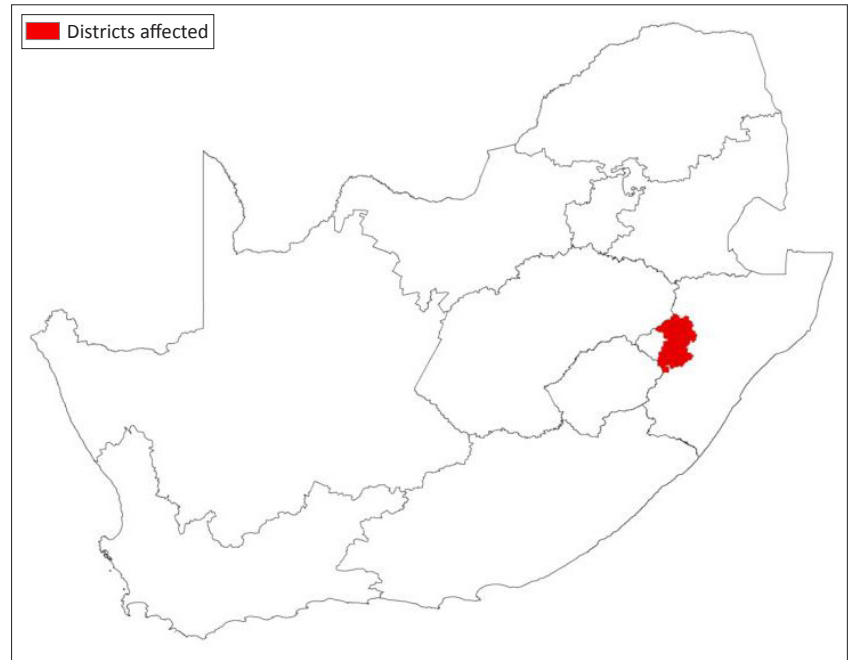

Post-1994 provincial boundaries are shown.

FIGURE 16: Districts affected by Rift Valley fever outbreaks in South Africa during 1990-1991. 


\section{1-1998}

According to the Directorate of Animal Health/Veterinary Services Disease database (Directorate of Animal Health 2012), no outbreaks of RVF were reported.

\section{9}

During January 1999 RVF was diagnosed in captive African buffalo (Syncerus caffer) in a boma (holding pen for wildlife) at Skukuza in the Kruger National Park (Figure 17) (State Veterinarian Skukuza 2000; Directorate of Animal Health 2012). Six buffalo cows aborted and positive virus isolation confirmed RVF. The virus was determined to belong to lineage C (Grobbelaar et al. 2011).

\section{0-2007}

No outbreaks of RVF were reported during this period (Directorate of Animal Health 2012).

\section{8}

Between January and June 2008 RVF was reported from the Nkomazi, Mbombela and Dr J.S. Moroka Local Municipalities in Mpumalanga, the Bela-Bela and BaPhalaborwa Local Municipalities in Limpopo, the Nokeng tsa Taemane, Tshwane and Kungwini Local Municipalities in Gauteng and the Potchefstroom, Moretele and Madibeng Local Municipalities in the North West Province (Figure 18) (Directorate of Animal Health 2012). A total of 15 outbreaks were reported, with 353 animal cases and 103 animal deaths. The species affected were cattle, goats, sheep and African buffalo (Directorate of Animal Health 2012). The National Institute for Communicable Diseases (NICD) (2008) reported 14 human cases during 2008 and lineage C RVF viruses were isolated from humans, cattle and African buffalo (Grobbelaar et al. 2011).

\section{9}

During February to June 2009 several outbreaks of RVF occurred in the Ingwe, Kwa Sani and uMngeni Local Municipalities in KwaZulu-Natal and the Matatiele Local Municipality in the Eastern Cape province, and one outbreak occurred in the Mbombela Local Municipality in Mpumalanga (Figure 19) (Directorate of Animal Health 2012). A total of 19 outbreaks were reported, with 210 animal cases and 66 animal deaths. The species affected were cattle and sheep (Directorate of Animal Health 2012). A lineage C RVF virus was isolated from several human cases (Grobbelaar et al. 2011).

During October to November 2009 the Northern Cape province experienced RVF outbreaks associated with irrigated lands along the lower Orange River in the Kakamas region (Directorate of Animal Health 2012). A total of 19 outbreaks were reported, with 53 animal cases and 35 animal deaths. The species affected were cattle, sheep and goats (Directorate of Animal Health 2012). The NICD (2009)

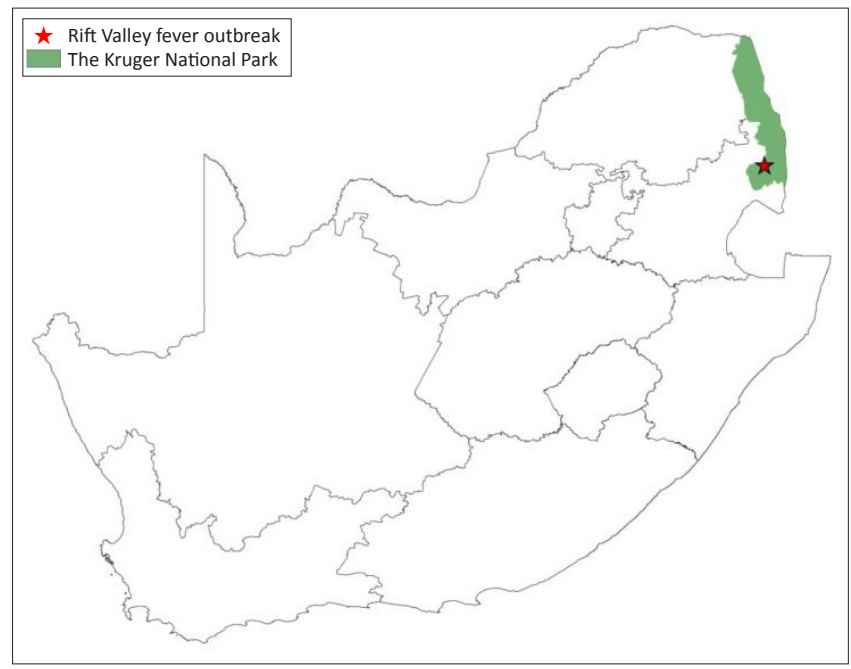

FIGURE 17: Rift Valley fever outbreak in captive African buffalo at Skukuza during January 1999.

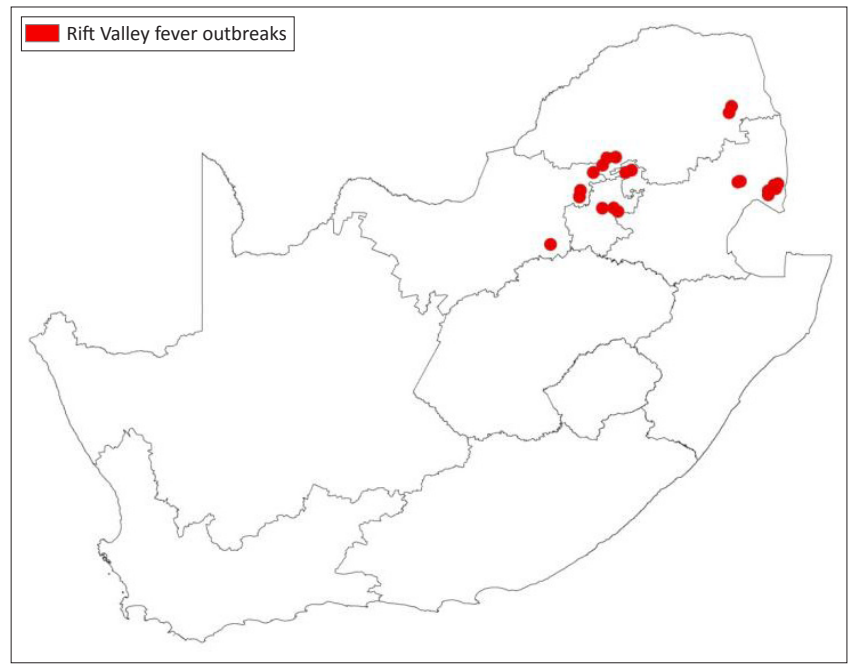

FIGURE 18: Rift Valley fever outbreaks in South Africa during 2008.

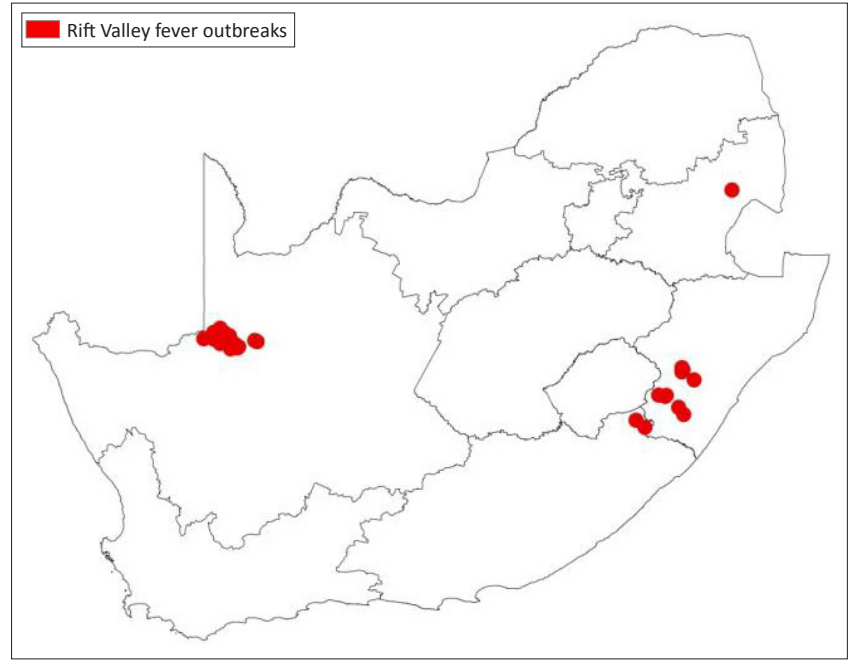

FIGURE 19: Rift Valley fever outbreaks in KwaZulu-Natal and Mpumalanga during February to June 2009 and in the Northern Cape during October to November 2009.

reported seven human cases associated with these outbreaks and a RVF virus, this time from lineage $\mathrm{H}$, was isolated (Grobbelaar et al. 2011). 


\section{0}

A major epidemic of RVF occurred during the first half of 2010. It was first reported from the Bultfontein and Brandfort areas of the Free State and ultimately spread to all provinces except KwaZulu-Natal. The Free State, Northern Cape and Eastern Cape were the most severely affected (Figure 20). The epidemic started in February 2010 and continued until June 2010. For the first time in the history of RVF in South Africa several outbreaks occurred in the winter rainfall region of the Western Cape (Directorate of Animal Health 2012). The virus responsible for the 2010 outbreaks belonged to lineage H (Grobbelaar et al. 2011).

During this period a total of 484 outbreaks were reported, with 14342 animal cases and 8877 animal deaths. The epidemic affected mostly sheep (13 117 cases reported) followed by cattle and goats. Indigenous wildlife that were reported to have shown signs of RVF during 2010 were springbok (Antidorcas marsupialis), blesbok (Damaliscus dorcas dorcas), bontebok (D. dorcas phillipsi), waterbuck (Kobus ellipsiprymnus), African buffalo, sable (Hippotragus niger), kudu (Tragelaphus strepsiceros), nyala (Tragelaphus angasii) and gemsbok (Oryx gazella). Some exotic species that were affected were fallow deer (Cervus dama), llama (Lama glama), alpaca (Lama pacos), Asian buffalo (Bubalus bubalis) and ibex (Capra ibex). In most of these indigenous and exotic wildlife species these were the first documented cases of RVF (Directorate of Animal Health 2012).

\section{1}

During 2011 a smaller epidemic of RVF occurred, involving mostly the Eastern Cape and some outbreaks in the Western and the Northern Cape provinces (Figure 21). A total of 135 outbeaks were reported, involving 4139 animals. Sheep were most affected (3491 animals), followed by goats (327 animals) and 195 cattle (Directorate of Animal Health 2012).

Wild animals affected were springbok, bontebok and buffalo. One fallow deer and a Cape hare (Lepus capensis) also showed clinical signs of RVF (Directorate of Animal Health 2012).

During 2012 no outbreaks of RVF were reported (Directorate of Animal Health 2012).

For easy reference, a summary of all the recorded laboratoryconfirmed RVF outbreaks in South Africa between 1950 and 2011 is given in Table 1 .

\section{Cumulative temporal and spatial distribution of outbreaks}

The temporal distribution and indication of the extent of the RVF outbreaks are shown in Figure 22. Prior to about 1990, bar heights overestimate the number of blocks that experienced outbreaks as some earlier reports mentioned only the veterinary region, in which case all the squares within that region were counted as having experienced an

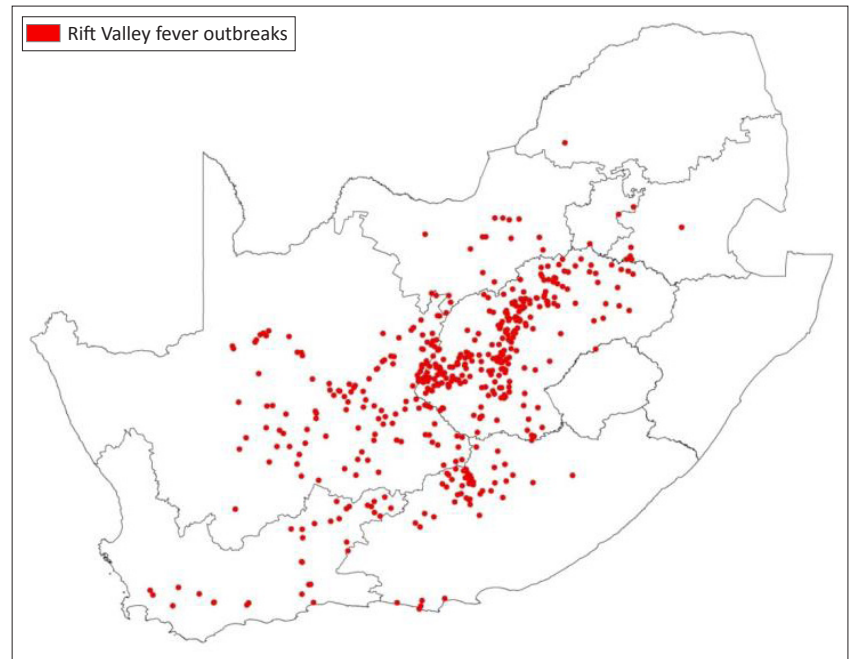

FIGURE 20: Rift Valley fever outbreaks in South Africa in 2010.

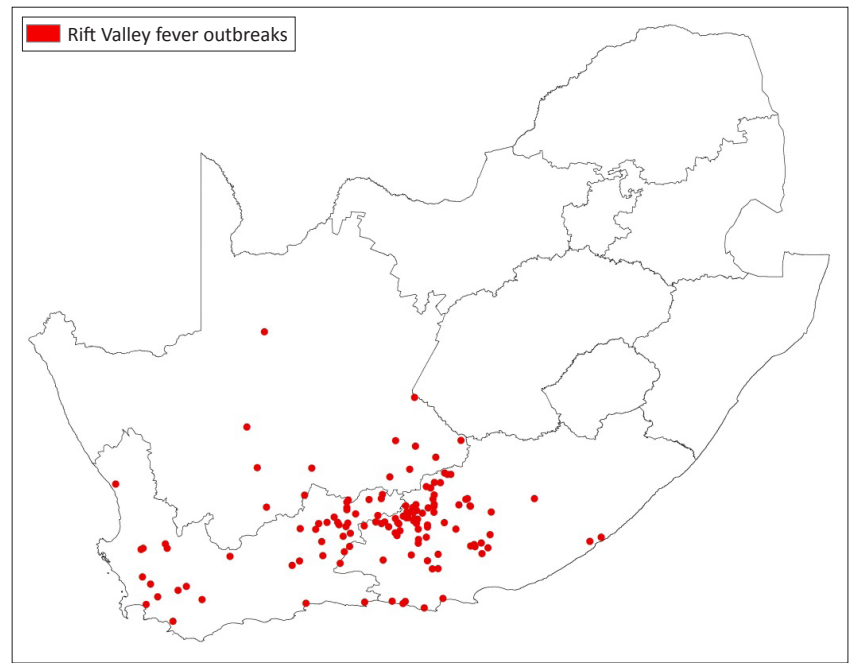

FIGURE 21: Rift Valley fever outbreaks in South Africa in 2011.

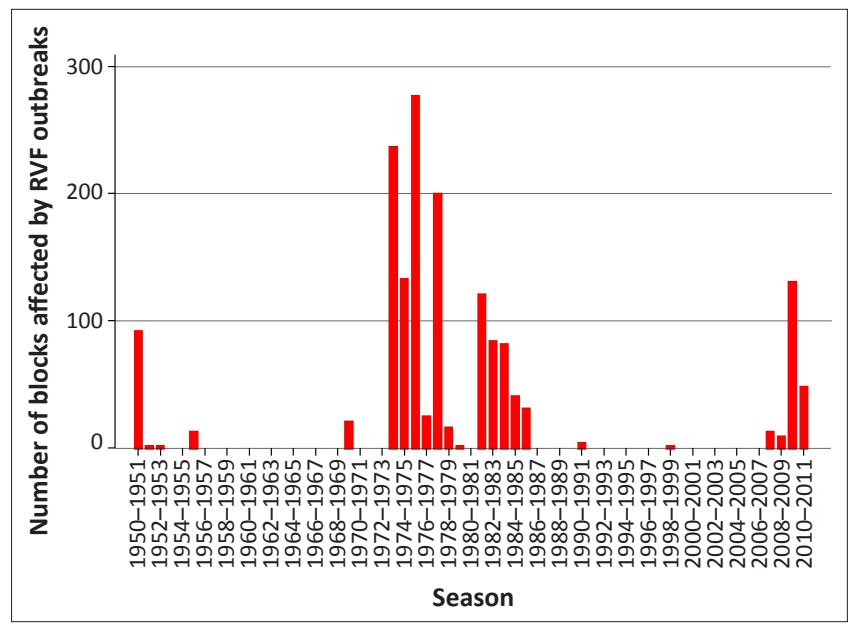

FIGURE 22: The temporal distribution of reported Rift Valley fever outbreaks in South Africa during the period 1950-2010.

outbreak. However, the three major RVF epidemics (19501951, 1973-1976 and 2010-2011) can be identified.

The geographic distribution of all the reported RVF outbreaks since 1950 and the cumulative number of seasons during 
TABLE 1: Summary of Rift Valley fever outbreaks in South Africa, 1950-2011.

\begin{tabular}{|c|c|}
\hline Period & Outbreak location and description \\
\hline $1950-1951$ & Northern Cape Province, western Orange Free State, southern Transvaal \\
\hline 1951-1952 & Boshof District, Orange Free State \\
\hline $1952-1953$ & Fauresmith District, Orange Free State \\
\hline 1955-1956 & Twenty-eight outbreaks reported from the Orange Free State \\
\hline 1956-1957 & Two outbreaks in the western Orange Free State \\
\hline 1969-1970 & $\begin{array}{l}\text { Severe losses occurred owing to outbreaks reported from the Standerton, Frankfort, Kroonstad, Koppies, Odendaalsrus, Vryburg and Lower } \\
\text { Umfolozi districts }\end{array}$ \\
\hline 1976-1977 & Isolated outbreaks in the Orange Free State, eastern Cape Province, northern Cape Province and Natal \\
\hline 1977-1978 & Some outbreaks reported from the Free State and the Eastern Cape and Karoo regions \\
\hline 1978-1979 & Some outbreaks reported from the Free State, Eastern Cape and Karoo, and the Natal regions \\
\hline 1979-1980 & A single outbreak reported in the Mtunzini District of Natal \\
\hline 1981-1982 & Some outbreaks reported from the Free State, Eastern Cape and Karoo, and the Natal region \\
\hline 1982-1983 & Small outbreaks reported from the Natal and Highveld regions \\
\hline 1983-1984 & Small outbreaks reported from the Natal and Western Cape regions \\
\hline 1985-1986 & $\begin{array}{l}\text { A total of } 13 \text { outbreaks reported from the Estcourt, Utrecht and Ubombo districts of the Natal region and seven outbreaks from the Port } \\
\text { Elizabeth, Middelburg, Beaufort West, Hofmeyer and Graaff Reinett districts of the Eastern Cape and Karoo region }\end{array}$ \\
\hline 1987-1988 & One outbreak reported from an unknown location \\
\hline 1989-1990 & One outbreak reported from an unknown location \\
\hline 1990-1991 & Five outbreaks reported from the Estcourt District and two from the Kliprivier District of Natal \\
\hline January 1999 & One outbreak amongst buffalo reported from Skukuza \\
\hline January-June 2008 & Several outbreaks reported from eastern Mpumalanga and from northern Gauteng and adjoining provinces \\
\hline February-June 2009 & Several outbreaks reported from southern KwaZulu-Natal and one from eastern Mpumalanga \\
\hline October-November 2009 & Several outbreaks reported form the Kakamas region of the Northern Cape \\
\hline 2010 & $\begin{array}{l}\text { Numerous outbreaks affecting all provinces except KwaZulu-Natal. The Free State, Northern Cape and Eastern Cape were the most severely } \\
\text { affected. }\end{array}$ \\
\hline 2011 & Many outbreaks, although fewer than 2010 , mostly in the Eastern Cape, but also in the Western and Northern Cape provinces \\
\hline
\end{tabular}

which at least one outbreak was recorded for each half degree square block are shown in Figure 23. For the same reason as in Figure 22 the extent of earlier outbreaks, particularly in the central and western regions, is overestimated. In contrast, because outbreaks in the eastern parts of the country generally remained localised, the relative frequency with which they were initiated in that region is under-emphasised in this representation. Nevertheless, the main region in which extensive outbreaks occurred is clearly visible in the central interior of the country.

For outbreaks where the actual month of occurrence was mentioned, Table 2 gives a summary of the months during which RVF outbreaks occurred during each season. Most outbreaks occurred from January onwards, but where outbreaks occurred before January, this often followed outbreaks late during the previous season.

\section{Discussion}

The search for documented outbreaks of RVF in South Africa yielded potentially useful results. For the first time the location and season of all the recorded RVF outbreaks in South Africa have been documented. This will facilitate further research into the epidemiology of the disease in South Africa and will promote a better understanding of the disease, leading to improved management, limiting the loss of livestock and human life. The poor spatial and, to a lesser extent, temporal precision in the reporting of earlier outbreaks undoubtedly reduced the accuracy of our calculated cumulative statistics prior to 1990 shown in Figures 22 and 23. Several other factors may have influenced

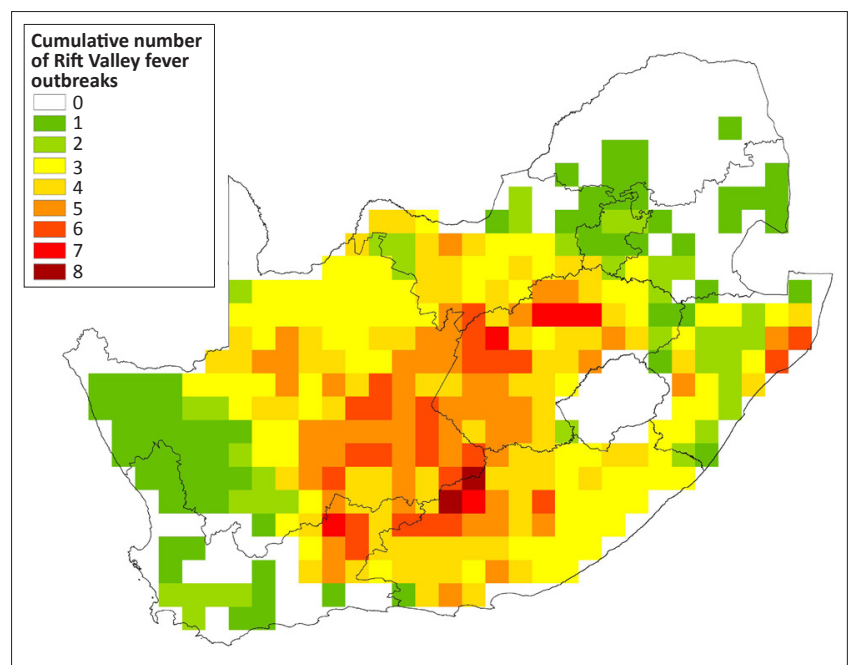

FIGURE 23: The cumulative number of seasons during which Rift Valley fever outbreaks occurred in South Africa during the period 1950-2011.

the reporting rate of RVF, including awareness by farmers, veterinarians and animal health workers, farmer perception and compliance, veterinary coverage of remote areas, and possibly low clinical expression of the disease in small, localised outbreaks. Nevertheless, it is likely that the status of RVF as a reportable or notifiable disease helped to ensure that the passive surveillance system captured most outbreaks of the disease.

Several outbreaks not previously recorded in the literature were documented during this study, for example the outbreaks during the 1978-1979 season and the small 
TABLE 2: The temporal distribution of Rift Valley fever outbreaks in South Africa (1950-2010) for each season where the month of the outbreak is known.

\begin{tabular}{|c|c|c|c|c|c|c|c|c|c|c|c|c|}
\hline Season & July & Aug. & Sept. & Oct. & Nov. & Dec. & Jan. & Feb. & Mar. & Apr. & May & June \\
\hline 1950-1951 & - & - & - & - & - & $*$ & - & $*$ & - & $*$ & - & - \\
\hline 1951-1952 & - & - & - & - & - & - & $*$ & - & - & - & - & - \\
\hline 1952-1953 & - & - & - & - & - & - & - & - & $*$ & - & - & - \\
\hline 1955-1956 & - & - & - & - & - & - & $*$ & $*$ & - & - & - & - \\
\hline 1969-1970 & - & - & - & - & - & - & - & $*$ & $*$ & - & - & - \\
\hline 1973-1974 & - & - & - & - & - & - & - & * & $*$ & $*$ & $*$ & * \\
\hline 1976-1977 & - & $*$ & $*$ & $*$ & $*$ & - & * & $*$ & $*$ & - & $*$ & - \\
\hline 1977-1978 & - & - & - & - & $*$ & - & $*$ & $*$ & - & - & $*$ & - \\
\hline 1978-1979 & - & - & - & - & $*$ & $*$ & - & $*$ & - & $*$ & - & - \\
\hline 1979-1980 & $*$ & - & - & - & - & - & - & - & - & & - & - \\
\hline 1981-1982 & - & - & - & - & - & - & - & - & - & $*$ & - & - \\
\hline 1982-1983 & - & - & - & - & - & - & - & - & $*$ & $*$ & - & $*$ \\
\hline 1983-1984 & - & - & - & $*$ & $*$ & $*$ & - & $*$ & & $*$ & - & - \\
\hline 1988-1989 & - & - & - & - & - & - & - & - & $*$ & - & - & - \\
\hline 1989-1990 & - & - & - & $*$ & - & - & - & - & - & - & - & - \\
\hline 1998-1999 & - & - & - & - & - & - & * & - & - & - & - & - \\
\hline 2007-2008 & - & - & - & - & - & - & $*$ & $*$ & $*$ & $*$ & $*$ & $*$ \\
\hline 2008-2009 & - & - & - & - & - & - & - & $*$ & $*$ & $*$ & $*$ & $*$ \\
\hline 2009-2010 & - & - & - & - & $*$ & - & - & $*$ & $*$ & $*$ & $*$ & $*$ \\
\hline 2010-2011 & - & - & - & - & $*$ & $*$ & $*$ & $*$ & $*$ & $*$ & $*$ & $*$ \\
\hline
\end{tabular}

*, Rift Valley fever outbreaks.

outbreaks between 1982 and 1985. The results indicate that the occurrence of RVF has been more frequent and more widespread than is generally believed, likely because the disease was often absent from an area for long periods and new farmers and veterinarians subsequently being unaware that an area had experienced outbreaks in the past. It is therefore imperative that farmers and veterinarians should continuously be made aware of the risk of RVF outbreaks and the need to vaccinate. The occurrence of a large epidemic in 2010 will increase awareness of RVF for several years to come, but the disease will likely largely disappear again and be forgotten in the future. This study can serve as motivation for vaccination programmes during interepidemic periods.

The general pattern that emerged from this analysis is that large epidemics tended to occur in the central parts of the country (Free State, Eastern Cape and Northern Cape), separated by long periods of absence or with small, localised intervening outbreaks. Smaller outbreaks tended to occur in the eastern parts of the country (KwaZulu-Natal and Gauteng). Outbreaks often occurred in these areas during the same season, but several times the outbreaks in the eastern part of the country were apparently not associated with those in the central region, for example in 1991, 2008 and 2009. Grobbelaar et al. (2011) showed that RVF virus isolates from across Africa grouped into 15 lineages, of which eight have been detected in South Africa, and that the viruses responsible for the outbreaks in the eastern parts of the country in 2008 and 2009 (lineage C) were different from those associated with outbreaks in the central regions in 2009 and 2010 (lineage H). Apart from this, differences in the pattern of outbreaks between the regions could not be identified during this study, but it is possible that different vector species are responsible (Jupp 2004). In addition, differences in climate, topography, vegetation and host populations are likely to have had a major influence, but fall beyond the scope of this paper and will be assessed in further analyses.
The reservoir or mechanism for maintenance of the RVF virus during interepidemic periods in South Africa has not been established; however, several possibilities exist. The first is that transovarial transmission takes place in certain Aedes spp. mosquitoes, associated with shallow grassland depressions or 'dambos' (Linthicum et al. 1985; Pepin et al. 2010). An increase in these mosquitoes triggers an outbreak, which is propagated by other mosquito species (Gerdes 2004). However, studies have not been able to demonstrate transovarial transmission in South Africa (McIntosh et al. $1980 \mathrm{~b})$. Each of the three major epidemics in the central interior of South Africa was associated with a different RVF virus lineage (Grobbelaar et al. 2011), indicating that longterm survival of virus in dormant mosquito eggs is unlikely to have been the main mechanism for virus survival between these epidemics. Another possibility is low-level circulation of virus between animals and vectors, without resulting in clinical signs or severe outbreaks (Pepin et al. 2010). Serological evidence of low-level circulation of RVF virus in African buffalo has been found in the Kruger National Park (R.G. Bengis, pers. comm., 27 October 2010) and antibodies have been found in several wildlife species in Kenya (Evans et al. 2008). Davies et al. (1992) also showed low-level circulation amongst cattle in Zambia. The possibility of an enzootic transmission cycle involving wildlife or domestic stock therefore requires further investigation. Incursions of vectors from possible endemic areas, either within South Africa or in neighbouring countries, is also a potential mechanism for initiation of outbreaks in South Africa and may be related to meteorological conditions. It is also possible that the movement of infected livestock or other unknown carriers could occur and initiate outbreaks. Closely related viruses have been isolated from geographically distant parts of Africa (Grobbelaar et al. 2011), suggesting that long-distance dispersal of either vectors or infected animals occurs, and phylogeographic analysis indicates a complex pattern of 
long-distance viral movement throughout Africa (Soumaré et al. 2012). Further investigation of the epidemiology of RVF and modelling of its transmission in southern Africa, taking into account virus phylogenetics and a variety of potential risk factors, is required to test these hypotheses.

Our analysis showed that most reported outbreaks occurred during mid to late summer, from January onwards. This coincided with the period of highest rainfall in most areas, which, coupled with warm temperatures, would have resulted in greater vector numbers. Where outbreaks occurred before January, this usually followed outbreaks late during the previous season; in other words, the epidemic 'survived' the winter. This was well documented during the period from 1974 to 1976, when outbreaks occurred throughout the winter of 1975 and continued into the next season when a warm, wet winter was experienced. This presumably resulted in the vectors maintaining the infection through the winter.

From the results (also see Figure 22) it is clear that certain areas were more prone to extensive RVF outbreaks. This agrees with a Kenyan study (Murithi et al. 2010), which showed that districts where outbreaks had occurred in the past were five times more likely to experience a subsequent outbreak. The areas in South Africa that experienced the most extensive outbreaks were in the central interior of the country, particularly the western Free State, north-western part of the Eastern Cape and the central part of the eastern Northern Cape.

The literature consulted for this study did not provide enough detail on the spread of RVF within a season, but the analysis of the 2010 epidemic suggests that the disease spreads from one area to the next once a large epidemic is triggered. A plausible explanation for this could be that enzootic vectors trigger the outbreak, which is then spread by epizootic vectors (Swanepoel 2009). Factors such as animal movement could also play an important role in the spread of the disease during an epidemic.

From the results it also becomes evident that after a large epidemic, such as the ones experienced during 1950-1951 and 1973-1976, outbreaks continue to occur for several years after the epidemic. This would suggest that South Africa may experience more outbreaks over the next few years in the wake of the 2010 epidemic. In addition, unless vaccination is continued, large epidemics are likely to recur once the proportion of immune animals in the population wanes and favourable environmental conditions occur. It is therefore necessary to raise awareness of this situation and to implement vaccination programmes that should be sustained through the interepidemic periods, particularly in the high-risk areas identified in this study. In addition, more research is required to investigate the mechanisms for RVF viral maintenance during interepidemic periods in southern Africa to elucidate the risk factors for not only the initiation but also the perpetuation of outbreaks. Findings will contribute to refine techniques for predicting future outbreaks.

\section{Acknowledgements}

The authors would like to thank Dr Grietjie de Klerk, Dr Sunelle Strydom and the late Dr Willie Ungerer for their assistance and patience in compiling this report, the Director of Animal Health for permission to conduct this study, and the provincial directors of Veterinary Services for permission to use their data. We also wish to thank all the national and provincial officials who assisted with the data collection. Three reviewers offered constructive comments, which helped to improve the manuscript.

\section{Competing interests}

The authors declare that they have no financial or personal relationship(s) that may have inappropriately influenced them in writing this article.

\section{Authors' contributions}

N.J.P. (University of Pretoria) performed the study and wrote the article. P.N.T. (University of Pretoria) was the academic study leader for the MSc degree of which this report formed part and assisted in study design, data analysis and writing of the article.

\section{References}

Alexander, R.A., 1951, 'Rift Valley Fever in the Union', Journal of the South African Veterinary Medical Association 22, 105-109.

Alexander, R.A., 1955a, 'Annual report for 1 July 1953 to 30 June 1954 of the Directorate of Veterinary Services', Department of Agriculture, Pretoria.

Alexander, R.A., 1955b, 'Jaarverslag vir 1 Julie 1954 tot 30 Junie 1955 vir die Afdeling Veeartsenydiens [Annual report for 1 July 1954 to 30 June 1955 of the Section Veterinary Services]', Department of Agriculture, Pretoria.

Alexander, R.A., 1956, 'Jaarverslag vir 1 Julie 1955 tot 30 Junie 1956 vir die Afdeling Veeartsenydiens [Annual report for 1 July 1955 to 30 June 1956 of the Section Veterinary Services]', Department of Agriculture, Pretoria.

Anonymous, 1976, 'Report on Rift Valley Fever from the Western Cape Veterinary region', Division of Veterinary Services, Department of Agriculture, Pretoria.

Barnard, B. \& Botha, M., 1977, 'An inactivated Rift Valley vaccine', Journal of the South African Veterinary Association 48, 45-48.

Daubney, R., Hudson, J.R. \& Garnham P.C., 1931, 'Enzootic hepatitis or Rift Valley Fever - An undescribed virus disease of sheep, cattle and man from East Africa' Journal of Pathology and Bacteriology 34, 545-579. http://dx.doi.org/10.1002/ path.170034041

Davies, F.G., Kilelu, E., Linthicum, K.J. \& Pegram, R.G., 1992, 'Patterns of Rift Valley fever activity in Zambia', Epidemiology and Infection 108, 185-191. http://dx.doi. org/10.1017/S0950268800049633

Directorate of Animal Health, 1980, 'Annual report for 1 July 1979 to 31 March 1980 of the Directorate of Animal Health', Department of Agriculture and Fisheries, Pretoria.

Directorate of Animal Health, 1981, 'Jaarverslag vir 1 April 1980 tot 31 Maart 1981 van die Direktoraat Dieregesondheid [Annual report for 1 April 1980 to 31 March 1981 of the Directorate of Animal Health]', Department of Agriculture and Fisheries, Pretoria.

Directorate of Animal Health, 1982, 'Jaarverslag vir 1 April 1981 tot 31 Maart 1982 van die Direktoraat Dieregesondheid [Annual report for 1 April 1981 to 31 March 1982 of the Directorate of Animal Health]', Department of Agriculture, Pretoria.

Directorate of Animal Health, 1989, 'Annual report for 1 April 1988 to 31 March 1989 of the Directorate of Animal Health', Department of Agricultural Economics and Marketing, Pretoria.

Directorate of Animal Health, 2012, 'National Animal Disease Database of the Directorate of Animal Health 1992 to 2012', Department of Agriculture, Forestry and Fisheries, Pretoria.

Directorate of Veterinary Services, 1985a, 'Annual report for 1 April 1984 to 31 March 1985 of the Directorate of Veterinary Services', Department of Agriculture, Pretoria.

Directorate of Veterinary Services, 1985b, 'Directorate of Veterinary Services report to the OIE for 1985', Department of Agriculture, Pretoria.

Directorate of Veterinary Services, 1985c, 'Disease report to the Southern African Regional Commission for the Conservation and Utilisation of the Soil (SARCCUS) for 1984', Department of Agriculture, Pretoria. 
Directorate of Veterinary Services, 1986a, 'Annual disease report to the OIE for 1986', Department of Agriculture, Pretoria.

Directorate of Veterinary Services, 1986b, 'Annual report for 1 April 1985 to 31 March 1986 of the Directorate of Veterinary Services', Department of Agriculture, Pretoria.

Directorate of Veterinary Services, 1987, 'Annual report for 1 April 1986 to 31 March 1987 of the Directorate of Veterinary Services', Department of Agriculture, Pretoria.

Directorate of Veterinary Services, 1988, 'Annual report for 1 April 1987 to 31 March 1988 of the Directorate of Veterinary Services', Department of Agricultura Economics and Marketing, Pretoria.

Directorate of Veterinary Services, 1989a, 'Directorate of Veterinary Services report to the OIE for 1987', Department of Agriculture, Pretoria.

Directorate of Veterinary Services, 1989b, 'Directorate of Veterinary Services report to the OIE for 1989', Department of Agriculture, Pretoria.

Director of Eastern Cape and Karoo region of Veterinary Services, 1986, 'Annual report for 1 April 1985 to 31 March 1986 of the Eastern Cape and Karoo region of the Directorate of Veterinary Services', Department of Agriculture, Pretoria.

Director of Natal region of Veterinary Services, 1986a, 'Monthly disease reports from the Natal region of the Directorate of Veterinary Services', Department of Agriculture, Pretoria.

Director of Natal region of Veterinary Services, 1986b, 'Annual report for 1 April 1985 to 31 March 1986 of the Natal region of the Directorate of Veterinary Services', Department of Agriculture, Pretoria.

Director of Natal region of Veterinary Services, 1991, 'Annual report for 1 April 1990 to 31 March 1991 of the Natal Veterinary region', Department of Agricultural Economics and Marketing, Pretoria.

Division of Veterinary Services, 1957, ‘Jaarverslag vir 1 Julie 1956 tot 1 Junie 1957 vir die Afdeling Veeartsenydiens [Annual report for 1 July 1956 to 1 June 1957 of the Division of Veterinary Services]', Department of Agriculture, Pretoria.

Division of Veterinary Services, 1958, 'Annual report of the secretary for Agriculture for the period 1st July, 1957 to 30th June, 1958', Department of Agriculture, Pretoria.

Division of Veterinary Services, 1959, 'Annual report for 1 July 1958 to 30 June 1959 of the Division of Veterinary Services', Department of Agriculture, Pretoria.

Division of Veterinary Services, 1960, 'Jaarverslag vir 1 Julie 1959 tot 1 Junie 1960 vir die Afdeling Veeartsenydiens [Annual report for 1 July 1959 to 1 June 1960 of the Division of Veterinary Services]', Department of Agriculture, Pretoria.

Division of Veterinary Services, 1961, 'Jaarverslag vir 1 Julie 1960 tot 1 Junie 1961 vir die Afdeling Veeartsenydiens [Annual report for 1 July 1960 to 1 June 1961 of the Division of Veterinary Services]', Department of Agriculture, Pretoria.

Division of Veterinary Services, 1962, 'Jaarverslag vir 1 Julie 1961 tot 1 Junie 1962 vir die Afdeling Veeartsenydiens [Annual report for 1 July 1961 to 1 June 1962 of the Division of Veterinary Services]', Department of Agriculture, Pretoria.

Division of Veterinary Services, 1963, 'Jaarverslag vir 1 Julie 1962 tot 1 Junie 1963 vir die Afdeling Veeartsenydiens [Annual report for 1 July 1962 to 1 June 1963 of the Division of Veterinary Services]', Department of Agriculture, Pretoria.

Division of Veterinary Services, 1964, 'Jaarverslag vir 1 Julie 1963 tot 1 Junie 1964 vir die Afdeling Veeartsenydiens [Annual report for 1 July 1963 to 1 June 1964 of the Division of Veterinary Services]', Department of Agriculture, Pretoria.

Division of Veterinary Services, 1965, 'Jaarverslag vir 1 Julie 1964 tot 1 Junie 1965 vir die Afdeling Veeartsenydiens [Annual report for 1 July 1964 to 1 June 1965 of the Division of Veterinary Services]', Department of Agriculture, Pretoria.

Division of Veterinary Services, 1966, 'Jaarverslag vir 1 Julie 1965 tot 1 Junie 1966 vir die Afdeling Veeartsenydiens [Annual report for 1 July 1965 to 1 June 1966 of the Division of Veterinary Services]', Department of Agriculture, Pretoria.

Division of Veterinary Services, 1967, 'Annual report for 1 July 1966 to 30 June 1967 of the Division of Veterinary Services', Department of Agriculture, Pretoria.

Division of Veterinary Services, 1968, 'Annual report for 1 July 1967 to 30 June 1968 of the Division of Veterinary Services', Department of Agriculture, Pretoria.

Division of Veterinary Services, 1969, 'Annual report for 1 July 1968 to 30 June 1969 of the Division of Veterinary Services', Department of Agriculture, Pretoria.

Division of Veterinary Services, 1970, 'Annual report for 1969/1970 of the Division of Veterinary Services', Department of Agriculture, Pretoria.

Division of Veterinary Services, 1971, 'Annual report for 1 July 1970 to 30 June 1971 of the Division of Veterinary Services', Department of Agriculture, Pretoria.

Division of Veterinary Services, 1972, 'Annual report for 1 July 1971 to 30 June 1972 of the Division of Veterinary Services', Department of Agriculture, Pretoria.

Division of Veterinary Services, 1973, 'Annual report for 1 July 1972 to 30 June 1973 of the Division of Veterinary Services', Department of Agriculture, Pretoria.

Division of Veterinary Services, 1974, 'Jaarverslag vir 1 Julie 1973 tot 1 Junie 1974 vir die Afdeling Veeartsenydiens [Annual report for 1 July 1973 to 1 June 1974 of the Division of Veterinary Services]', Department of Agriculture, Pretoria.

Division of Veterinary Services, 1975, 'Annual report for 1 July 1974 to 30 June 1975 of the Division of Veterinary Services', Department of Agriculture.

Division of Veterinary Services, 1976a, 'Annual report for 1 July 1975 to 30 June 1976 of the Division of Veterinary Services', Department of Agriculture, Pretoria.

Division of Veterinary Services, 1976b, 'Monthly disease reports from veterinary regions during 1976', Department of Agriculture, Pretoria.
Division of Veterinary Services, 1977a, 'Annual report for 1 July 1976 to 30 June 1977 of the Division of Veterinary Services', Department of Agriculture, Pretoria.

Division of Veterinary Services, 1977b, 'Monthly disease reports from veterinary regions during 1977', Department of Agriculture, Pretoria.

Division of Veterinary Services, 1978a, 'Annual report of the Division of Veterinary Services, 1977-1978', Department of Agricultural Technical Services, Pretoria.

Division of Veterinary Services, 1978b, 'Monthly disease reports from veterinary regions during 1978', Department of Agricultural Technical Services, Pretoria.

Division of Veterinary Services, 1979, 'Monthly disease reports from veterinary regions during 1979', Department of Agricultural Technical Services, Pretoria.

Division of Veterinary Services, 1983a, 'Disease report to the Southern African Regional Commission for the Conservation and Utilisation of the Soil (SARCCUS) for 1982', Department of Agriculture, Pretoria.

Division of Veterinary Services, 1983b, 'Annual report for 1 April 1982 to 31 March 1983 of the Division of Veterinary Services', Department of Agriculture, Pretoria.

Division of Veterinary Services, 1984a, 'Disease report to the Southern African Regional Commission for the Conservation and Utilisation of the Soil (SARCCUS) for 1983', Department of Agriculture, Pretoria.

Division of Veterinary Services, 1984b, 'Jaarverslag vir 1 Julie 1983 tot 1 Junie 1984 vir die Afdeling Veeartsenydiens [Annual report for 1 July 1983 to 1 June 1984 of the Division of Veterinary Services]', Department of Agriculture, Pretoria.

Evans, A., Gayuka, F., Paweska, J.T., Rostal, M., Akoolo, L., Van Vuren, P.J. et al., 2008, 'Prevalence of antibodies against Rift Valley fever virus in Kenyan wildlife', Epidemiology and Infection 136, 1261-1269. http://dx.doi.org/10.1017/ S095026880700980

Gage, K.L., Burkot, T.R., Eisen, R.J. \& Hayes, E.B., 2008, 'Climate and vectorborne diseases', American Journal of Preventive Medicine 35, 436-450. http://dx.doi. org/10.1016/j.amepre.2008.08.030

Gear, J., Meillo, B.D., Roux, A.F.L., Kofsky, R., Innes, R.R., Steyn, J.J. et al., 1955, 'Rift Valley fever in South Africa: A study of the 1953 outbreak in the Orange Free State, with special reference to the vectors and possible reservoir hosts', South African Medical Journal 514-518.

Gerdes, G.H., 2004, 'Rift Valley Fever', Revue Scientifique Technique Office Internationa Des Epizooties 23, 613-623.

Grobbelaar, A.A., Weyer, J., Leman, P.A., Kemp, A., Paweska, J.T. \& Swanepoel, R., 2011, 'Molecular epidemiology of Rift Valley fever virus', Emerging Infectious Diseases 17, 2270-2276. http://dx.doi.org/10.3201/eid1712.111035

Jupp, P.G., 2004, 'Vectors: Mosquitoes', in J.A.W. Coetzer \& R.C. Tustin (eds.), Infectious Diseases of Livestock, 2nd edn., pp. 137-152, Oxford University Press, Cape Town.

Linthicum, K.J., Anyamba, A., Tucker, J.T., Kelley, P.W., Myers, M.F. \& Peters, C.J., 1999, 'Climate and satellite indicators to forecast Rift Valley fever epidemics in Kenya', Science 285, 397-400. http://dx.doi.org/10.1126/science.285.5426.397

Linthicum, K.J., Davies, F.G., Kairo, A. \& Bailey, C.L., 1985, 'Rift Valley fever virus (family Bunyaviridae, genus Phlebovirus). Isolations from Diptera collected during
an inter-epizootic period in Kenya', The Journal of Hygiene 95, 197-209. http:// an inter-epizootic period in Kenya', The Jour
dx.doi.org/10.1017/S0022172400062434

McIntosh, B.M., Russell, D., Dos Santos, I. \& Gear, J.H.S., 1980a, 'Rift Valley fever in humans in South Africa', South African Medical Journal 58, 803-806.

McIntosh, B.M., Jupp, P.G., Dos Santos, I. \& Barnard, B.J.H., 1980b, 'Vector studies on Rift Valley fever virus in South Africa', South African Medical Journal 58, 127-132.

Mundel, B. \& Gear, J., 1951, 'Rift Valley Fever. I. The occurrence of human cases in Johannesburg', South African Medical Journal 25, 797-800.

Murithi, R.M., Munyua, P., Ithondeka, P., Macharia, J., Hightower, A., Luman, E.T. et al., 2010, 'Rift Valley fever in Kenya: History of epizootics and identification of vulnerable districts', Epidemiology and Infection 139, 372-380. http://dx.doi. org/10.1017/S0950268810001020

National Institute for Communicable Diseases, 2008, Communicable Diseases Communique, newsletter, South African National Health Laboratory Service, National Institute for Communicable Diseases 7, 6

National Institute for Communicable Diseases, 2009, Communicable Diseases Communique, newsletter, South African National Health Laboratory Service, National Institute for Communicable Diseases 8, 11.

Pepin, M., Bouloy, M., Bird, B.H., Kemp, A. \& Paweska, J., 2010, 'Rift Valley fever virus (Bunyaviridae: Phlebovirus): An update on pathogenesis, molecular epidemiology, vectors, diagnostics and prevention', Veterinary Research 41, 61-100. http:// dx.doi.org/10.1051/vetres/2010033

Soumaré, P.O.L., Freire, C.C.M., Faye, O., Diallo, M., De Oliveira, J.V.C., Zanotto, P.M.A et al., 2012, 'Phylogeography of Rift Valley fever virus in Africa reveals multiple introductions in Senegal and Mauritania', PLoS One 7, e35216. http://dx.doi. org/10.1371/journal.pone.0035216

State Veterinarian Skukuza, 2000, 'Annual Report for January 1999 to December 1999', Directorate of Veterinary Services.

Swanepoel, R. \& Coetzer, J.A.W., 2004, 'Rift Valley Fever', in J.A.W. Coetzer \& R.C. Tustin (eds.), Infectious Diseases of Livestock, 2nd edn., pp. 1037-1070, Oxford Tustin (eds.), Infectious Diseases
University Press, Cape Town.

Swanepoel, R., 2009, 'Re-emergence of Rift Valley Fever in South Africa: How can we better predict and respond?', keynote address at the OIE regional seminar on Rift Valley fever, Bloemfontein, 16-18 February.

Van der Linde, N.T., 1953, 'A recent epidemic of Rift Valley Fever in the Orange Free State', Journal of the South African Veterinary Medical Association 24, 145-148. 